\title{
Entrepreneurs Characteristics of Thematic Small and Medium Industries in Innovation Sub District of Palu City
}

\author{
Rosida P. Adam ${ }^{1}$, Zakiyah Zahara ${ }^{1}$, Suardi $^{1} \&$ Idris $^{1}$ \\ ${ }^{1}$ Faculty of Management Economics, Tadulako University, Palu, Central Sulawesi, Indonesia \\ Correspondence: Rosida P. Adam, Faculty of Management Economics, Tadulako University, Palu, Central Sulawesi, \\ Indonesia. Tel: 62-813-5424-1783.
}

Received: February 21, 2021

Accepted: March 22, 2021

Online Published: May 6, 2021

doi:10.5430/ijfr.v12n4p179

URL: https://doi.org/10.5430/ijfr.v12n4p179

\begin{abstract}
Nowadays, the development and growth of Small and Medium Industries (SMEs) have become the government's centre of attention which leads the government's commitment, policies and programs are always continuously improved, with the aim that SMEs in Indonesia can keep developing and being competitive. SMEs play an important role in being the backbone of the national economy, and they are even able to stand up straight during unstable global economic conditions. Therefore, this research aimed to produce a Model of the Success of Thematic SMEs in the Innovation Sub district of Palu City, which was predicted to be influenced by the variables of characteristics of group ethnic entrepreneurs, marketing innovation, and the competence of counterparts. The research sample consisted of 150 business group members from 30 Thematic SMEs, analysed using structural equation modelling (PLS-SEM). The results showed that of the seven research hypothesis models, the results were acceptable with the structural model constructed, namely the characteristics of group ethnic entrepreneurs, marketing innovation and the competence of counterparts influenced significantly on the success of the Thematic SMEs businesses in Innovation Sub-districts in Palu City. The biggest influence contribution was the competence of business counterparts by 0.526 , and the group ethnic entrepreneurship on the marketing innovation by 0.443 .
\end{abstract}

Keywords: ethnic entrepreneurs, marketing innovation, counterparts and the success of business

\section{Introduction}

Today's development and growth of Small and Medium Industries (SMEs) cannot be separated from the presence of government's sustainable commitment, policies and programs with the aim that SMEs in Indonesia can keep developing and being highly competitive so that they can compete in the global economy. SMEs play an important role in being the backbone of the national economy, and they are even able to stand up straight during unstable global economic conditions. As we know, SMEs themselves are the majority sector of the industrial population in Indonesia. So far, their activities have consistently brought about broad multiplier effects in order to promote equitable distribution of social welfare. The number of SMEs in Indonesia is 4.4 million business units, or $99 \%$ of all industrial business units in the country. The former Minister of Industry of Indonesia, Airlangga Hartanto, argued that SMEs played an important role in the national economic development, and this was due to the relatively stable growth of SMEs. In addition, the ability of SMEs to absorb labours was exceedingly high, reaching $97.22 \%$ at the beginning of 2018.

According to the ability of SMEs that can absorb labours as well as to boost people's income, the Government of Palu City executes the $3^{\text {rd }}$ mission, that is, the science and technology-based superior innovation subdistricts by developing SMEs based on the potential of each area. Planned in the period of 2016 to 2021, the number of Thematic SMEs is set at 20 Thematic with 30 types of businesses, also assisted by 45 counterparts consisting of 12 technical counterparts and 33 business management counterparts (Department of Industry and Trade of Palu City, 2019). It is known that a lot of human power can be replaced by mechanical and automatic tools, however in many cases, humans are still needed, especially in controlling mechanical equipment (Hakim and Prajanti, 2019).

In the assistance, professional competence is required. In addition, the continuous development creates a marketing innovation carried out by SMEs in the context of the business success, marked by increased sales and market segmentation. According to Cummins, et al. (2000), that innovation can include the development of new products which incorporate innovative development in other aspects of marketing; these innovations are partly based on a 
sustainable environmental assessment of a dynamic market, which is very important to ensure the growth of businesses in very tense competitions. To deal with tough competitions, established SME groups are required to have an entrepreneurial spirit as a capital of human resources, along with various cultures and ethnicities that can be used as excellences from the aspects of togetherness and mutual cooperation which are considered as local wisdom.

The fostered groups of innovation subdistricts which are established in each subdistrict have various ethnic characters, namely: kaili and non-kaili ethnicities. The nature of the entrepreneurial spirit between ethnicities can affect the success of businesses. Research by Hastuti, et al. (2015), Munir (2013) and Riyanti (2007) found that there are differences in the dynamics of entrepreneurial characters between ethnic groups. Based on the description above, this study aims to explain and analyse influences of the characteristics of business group ethnic entrepreneurs on marketing innovation and the success of SME businesses.

\section{Development Model}

\subsection{Characteristics of Group Ethnic Entrepreneurs}

Ethnic entrepreneurship is a new field according to Anderson and Dana (2007), Naudé and Havenga (2007), especially in developing countries. Norms of cultures, beliefs and values not only influence entrepreneurial success, but also influence the economic success of business owners (Anderson and Dana 2007). However, some researchers argue that entrepreneurial attitudes on risks in decision making may not be culturally bound (McGrath, et al., 1992). The characteristics in empirical research conducted by Najim, et al. (2014), measure that characteristics of entrepreneurs are divided into 3 dimensions: personal, entrepreneurial, and managerial and organizational.

\subsection{Competence of Counterparts}

The Government Regulation of the Republic of Indonesia Number 29 of 2018 concerning Industrial Empowerment explains that assistance is a supervision activity to help improve the technical and managerial capabilities of SME companies, carried out continuously within a certain period. The assistance as referred to in Article 16 paragraph (1) is carried out by placing experts, TPL, and/or SME Consultants in SME business units and/or IKM Centres. (2) The assistance as referred to in paragraph (1) includes: a. business management; b. mastery of technology; c. production process and layout of machines/equipment; d. quality system and quality standards; e. product design; f. packaging design; and/or g. intellectual property rights. In addition, the success of businesses according to Blackman (2003) the dependent consists of four performance criteria: (a) Profitability, (b) Ability to fulfil obligations, (c) Ability to build up, and (d) Reputation and relationships with stakeholders.

\subsection{Marketing Innovation}

Technology and information facilitate the competitive marketing innovation (Freeman, 1995; Sood \& Tellis, 2009). The concept of innovation has been understood by researchers from various aspects of business and management (Carneiro, 2000; Hunt \& Morgan, 1995). Researchers Cohen \& Levinthal (1989), Freeman (1995), Sood \& Tellis (2009), consider innovation marketing from the perspective of product, process and marketing as one way to get optimal results. Innovation as a tool that enables humans to efficiently use their resources to develop competitive advantage (Knight \& Cavusgil, 2004). Furthermore, the concept of a small business marketing innovation model according to Michele, et al. (2009), is Marketing variables, Modification, Customer focus, Integrated marketing, Market focus and Unique proposition.

\subsection{Success of Business}

Achieving better performance depends not only on the successful application of tangible assets and natural resources, but also on effective knowledge management (Lee \& Sukoco, 2007). Regarding the success of the Thematic SME businesses, researchers refer to the Thematic SMEs Roadmap that has been targeted by the government. The success of SME businesses is measured from the roadmap stages, namely: Strengthening of human resources, strengthening of SME institutions, strengthening production, development of production and markets, and massive production (independent and bankable).

\section{Methodology}

\subsection{Samples and Data Collection}

The research population was all Thematic SMEs included in the innovation subdistricts area, with the total of 30 SMEs and averagely consisting of 5 to 10 people (group members) in each SME; however, the average active people were 5 so the number of sub-populations was 30 SMEs $\times 5$ members $=150$ people. Due to the small number of sub-populations, all SMEs members became the research samples. The data collection in this research was carried out to obtain the information needed. There were several data collection techniques through field research and literature. 


\subsection{SEM Process}

The hypotheses in this research were tested using covariance-based structural equation modelling (SEM). The covariance-based system is considered as a better method to use when a research aims to test hypotheses (Chin, 1995). The SEM approach maximizes the interpretability of measurement and structural models (Anderson and Gerbing, 1988; Hair, et al., 2006). The first step involvement is to ascertain the falsifiability of the constructs and variables embedded in the propositions and hypotheses according to Bacharach (1989) with separate estimates and, if necessary, the measurement model specification (Anderson and Gerbing, 1988). The second step in the SEM process is the simultaneous estimation of the measurement and structural sub-models (Anderson and Gerbing, 1988). The estimation path that connects the measured item with the constructs involved in calculating the structural path estimation. The calculations are carried out twice, firstly for measurements, and secondly for structural models (Hair, et al., 2006). The research population was all 30 Thematic SMEs included within the innovation subdistricts area, with the number of group members averagely 5 to 10 people in each SME. However, about 5 people who were active averagely, so that the number of sub-populations was 30 SMEs $x 5$ members $=150$ people. Due to the small number of sub-populations, all members of SMEs became the research samples.

\subsection{Measuring Validity}

The Inner Model or Outer Model determines how each indicator block is associated with latent variables. The Outer Model with reflexive indicators is evaluated by convergent and discriminant validity from indicators and reliability of composites for block indicators. Convergent validity is used to determine the validity of any relationship between indicators and the constructed latent (variables). An individual's reflexive size is said to be high if it is more than 0.70 (Ghozali, 2015). Based on these criteria, the indicator whose loading value is less than 0.70 is excluded from the analysis and re-estimated. However, for research in the early stages of developing a measurement scale the loading value of 0.5 to 0.60 is considered sufficient (Chin, 1998). Discriminant validity can be seen from cross loading or by comparing the AVE root of each latent variable construct with the correlation between constructs. While the indicator block assessment is carried out using reliability composites. According to Ghozali (2015), one indicator has good reliability with the value above 0.7 . The test results can be seen in Table 1 below.

Table 1. Validity dan reliability analysis results

\begin{tabular}{|c|c|c|c|c|c|c|}
\hline Variable & Dimension & Indicator & Loading & $\begin{array}{l}\text { Cronbach } \\
\text { Alpha }\end{array}$ & $\mathrm{CR}$ & AVE \\
\hline \multirow{12}{*}{$\begin{array}{l}\text { Characteristics = } \\
\text { Ethnic } \\
\text { Entrepreneurs of } \\
\text { SME Groups }\end{array}$} & \multirow{7}{*}{$\begin{array}{l}\text { Personal } \\
\text { (individual) }\end{array}$} & Having Sense of Strength & 0.779 & \multirow{7}{*}{0.884} & \multirow{7}{*}{0.909} & \multirow{7}{*}{0.589} \\
\hline & & Independence & 0.809 & & & \\
\hline & & $\begin{array}{l}\text { Personal passion for } \\
\text { project or work activities }\end{array}$ & 0.756 & & & \\
\hline & & $\begin{array}{l}\text { Optimism } \\
\text { self-confidence }\end{array}$ & 0.652 & & & \\
\hline & & Courage & 0.767 & & & \\
\hline & & Responsibility & 0.785 & & & \\
\hline & & $\begin{array}{l}\text { High motivation for } \\
\text { self-achievement }\end{array}$ & 0.812 & & & \\
\hline & \multirow{4}{*}{ Entrepreneur } & Future vision booster & 0.814 & \multirow{4}{*}{0.739} & \multirow{4}{*}{0.835} & \multirow{4}{*}{0.559} \\
\hline & & Risks taking & 0.757 & & & \\
\hline & & Ability to take chances & 0.741 & & & \\
\hline & & Thinking flexible & 0.671 & & & \\
\hline & $\begin{array}{l}\text { Management } \\
\text { and } \\
\text { organisation }\end{array}$ & Management skill & 0.604 & 0.888 & 0.913 & 0.604 \\
\hline
\end{tabular}




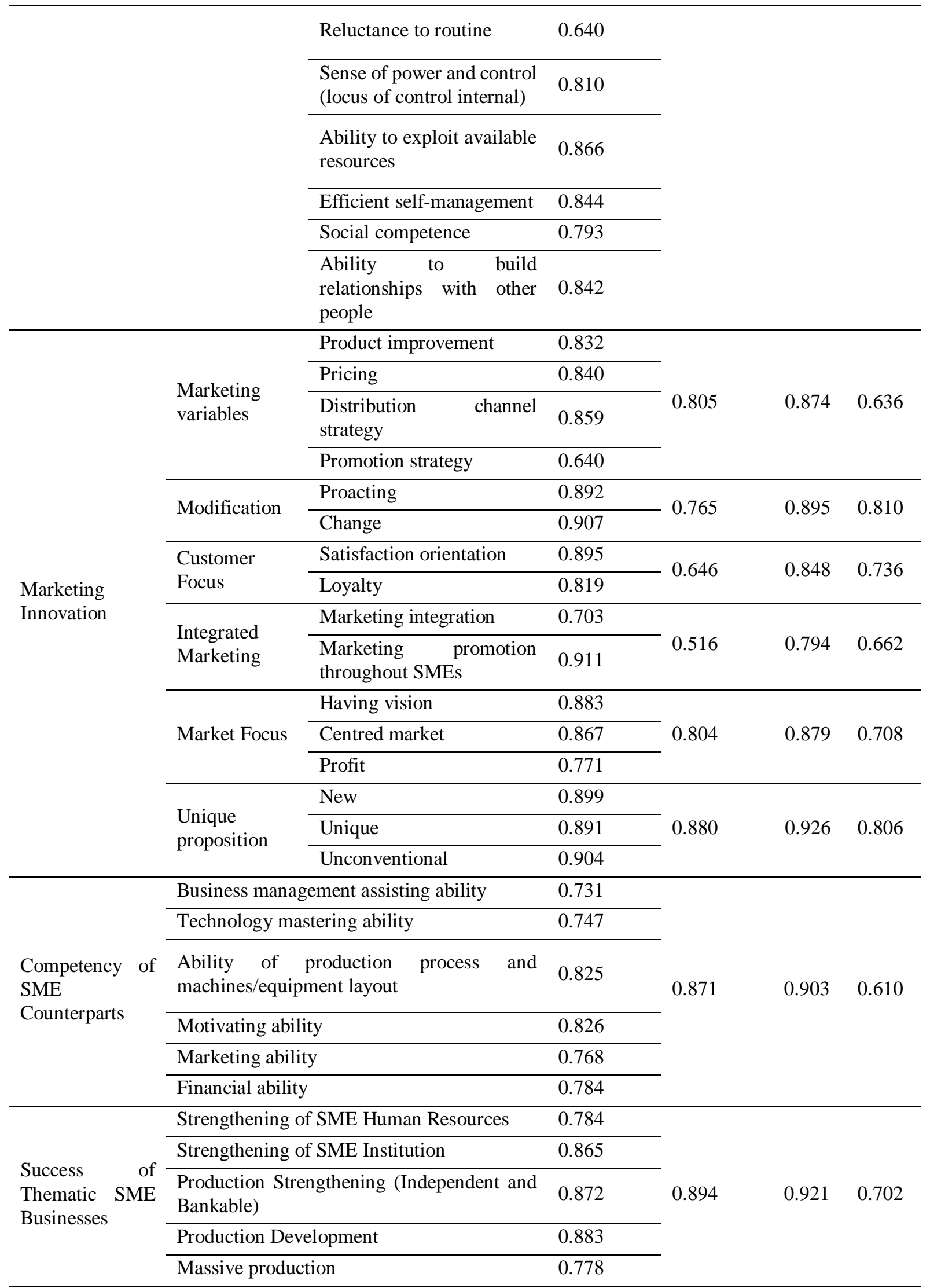

Source: Processed primary data, August 2020 
The Table 1 above shows the results of outer loading (parameter estimation) for each indicator (manifest variable) construction (latent variable) Characteristics of Ethnic Entrepreneur of SME Groups (KW), Marketing Innovation (IM), Competence of SME Counterparts (KTP), Success of Thematic SME Businesses (KU). From the parameter estimation values, around 45 indicators appear. The loading value results show that all indicators have a loading value of more than 40 indicators, more than 0.70 , and 5 indicators are less than 0.70 , namely 0.60 , thus according to Chin (1998), the early-stage research of developing a loading value measurement scale of 0.5 to 0.60 is considered sufficient. Therefore, all indicators are valid for use in model testing, and have good discriminant validity. On the other hand, the AVE and AVE root values in Table 24 indicate that the AVE root in each construct is higher than the correlation between this construct and the others. Meanwhile, the reliability of the composite value for all variables is above 0.70 . Hence, the built construct shows accuracy and precision of the measurement or reliable.

\section{Results}

Inner Model describes the relationship between latent variables based on substantive theory. Assessing the inner model is by looking at the relationship between latent constructs by seeing the result parameters of the path coefficient estimation and the significance level. Testing hypotheses can be seen from the values of $t$-statistic and probability. The hypothesis test uses statistical values, then for the 5\% alpha of $t$-statistic used is 1.96 , so that the criteria for the hypothesis acceptance/rejection are $\mathrm{Ha}$ accepted and $\mathrm{H} 0$ rejected when the $t$-statistic is $>1.96$. To reject/accept the hypothesis using probability, then Ha is accepted if the $p$ value is $<0.05$. The hypothesis test can be done by significance level and path parameters between latent variables as shown in Table 2 below.

Table 2. Model test

\begin{tabular}{lllll}
\hline Hypothesis & $\begin{array}{l}\text { Path } \\
\text { Coefficient }\end{array}$ & T Statistic & P Value & Result \\
\hline $\mathrm{KW} \rightarrow \mathrm{IM}$ & 0.443 & 6.652 & 0.000 & Accepted \\
\hline $\mathrm{KTP} \rightarrow \mathrm{IM}$ & 0.334 & 5.010 & 0.000 & Accepted \\
\hline $\mathrm{KTP} \rightarrow \mathrm{KU}$ & 0.526 & 5.580 & 0.000 & Accepted \\
\hline $\mathrm{KW} \rightarrow \mathrm{KU}$ & 0.159 & 2.410 & 0.016 & Accepted \\
\hline $\mathrm{IM} \rightarrow \mathrm{KU}$ & 0.276 & 4.516 & 0.000 & Accepted \\
\hline $\mathrm{KW} \rightarrow \mathrm{IM} \rightarrow \mathrm{KU}$ & 0.122 & 3.475 & 0.001 & Accepted \\
\hline $\mathrm{KTP} \rightarrow \mathrm{IM} \rightarrow \mathrm{KU}$ & 0.092 & 3.457 & 0.001 & Accepted \\
\hline
\end{tabular}

Source: Processed primary data, August 2020

After seeing the results of the model test above, it is necessary to look at the relationship strength (R-Square). The $\mathrm{R}$-Square value is shown in Table 3 below:

Table 3. Research hypothesis test

\begin{tabular}{lllll}
\hline Hypothesis & T Statistic & P Value & R-Square & Information \\
\hline $\mathrm{KW} \rightarrow \mathrm{IM}$ & 6.652 & 0.000 & \multirow{2}{*}{0.510} & Significant \\
\cline { 1 - 3 } $\mathrm{KTP} \rightarrow \mathrm{IM}$ & 5.010 & 0.000 & & Significant \\
\hline $\mathrm{KTP} \rightarrow \mathrm{KU}$ & 5.580 & 0.000 & & Significant \\
\cline { 1 - 2 } $\mathrm{KW} \rightarrow \mathrm{KU}$ & 2.410 & 0.016 & & Significant \\
\cline { 1 - 2 } $\mathrm{IM} \rightarrow \mathrm{KU}$ & 4.516 & 0.000 & & Significant \\
\cline { 1 - 2 } $\mathrm{KW} \rightarrow \mathrm{IM} \rightarrow \mathrm{KU}$ & 3.475 & 0.001 & & Significant \\
\hline $\mathrm{KTP} \rightarrow \mathrm{IM} \rightarrow \mathrm{KU}$ & 3.457 & 0.001 & & Significant \\
\hline
\end{tabular}

Source: Processed primary data, August 2020 
Based on Table 3 above, the test of the relationship between the characteristics of group ethnic entrepreneurs, the competency of SME counterparts, and the Marketing Innovation (KW-KTP-IM), it shows that the R-Square value is 0.51. The results show that the Marketing Innovation can be defined by the variable of characteristics of group ethnic entrepreneurs and the competence of counterparts around 51\%; meanwhile, the remaining $49 \%$ is defined by other variables in this research. The KW-IM-KTP-KU test shows that the R-Square value is 0.73 . This indicates that the success of businesses can be defined by the variables (characteristics of entrepreneurs, marketing innovation, and competency of counterparts) by $73 \%$, while the remaining $27 \%$ is defined by other variables outside of this research.

\section{Discussion}

This research focuses on the variables of the characteristics of group ethnic entrepreneurs, the marketing innovation, the competence of counterparts, and the success of businesses. Based on these variables, this research is made into seven hypotheses. The first hypothesis (Table 2 and Table 3 ) is the characteristics of group ethnic entrepreneurs with the marketing innovation. According to the data analysis, it turns out that these two variables have a significant influence, so that the characteristics of group ethnic entrepreneurs such as individual character, entrepreneurial spirit, and organizational management can influence the success of SMEs in Palu City. Individual characters such as businessmen' experiences and somebody's psychological profile are the standard. These individual measures can lead to a sense of risks tolerance and more innovative since they manage the uncertainty associated with innovative products or services, better (Marcati, et al., 2008; Shane, 2001; Fuentelsaz, et al., 2018; Arenius and Minniti, 2005; Cliff, et al., 2006; Shane 2000 and Venkataraman 1997). Meanwhile, according to Singh, et al. (2013), characteristics of entrepreneurship, structure of organization, and corporate cultures can create successful SMEs. And then the research shows that the traditional family business model that presents ethnic products penetrates into the mainstream market, and accesses mainstream information to increase the company's ability to be proactive in the market, facing business risks and lead to internal innovation (Wang \& Altinay, 2012; Dana, 2007; Naudé dan Havenga, 2007; Naudé and Havenga, 2007; Anderson and Dana, 2007; Arenius and Minniti, 200; Valliere, 2013).

The second hypothesis (Table 2 and Table 3) is the competence of counterparts and the marketing innovation. Based on the data analysis, there is a significant influence between the competence of counterparts and the marketing innovation. And so forth from this result, the government must be able to also provide kinds of knowledge improvement such as training and workshops to the counterparts aside of to each IKM previously since it will increase the innovation for SMEs in Palu City. The knowledge possessed by the counterparts is then delivered to the businessmen in order to add new knowledge and experiences which become the basis for innovating the products to be marketed (Palimbong, et al., 2019; Pratiwi, et al., 2019; Assegaf, 2015). Later, the most important thing is that the business management ability can have positive impacts on innovation improvement on the business being carried out (Andreeva, 2011; Martinez-Conesa, et al., 2017; Aditya, 2019; Gunawan, et al., 2019; Sianipar, et al., 2019; Taghizadeh, et al., 2020). However, lots of literature states that the company's innovation strategy depends on internal and external factors (Gibson and Birkinshaw, 2004; Martinez-Conesa, et al., 2017; Taghizadeh, et al., 2020), and Lichtenthaler (2009) particularly agrees that management capabilities are needed to successfully implement innovation in the company (Jansen, et al., 2006; Martinez, et al., 2017).

The third hypothesis (Table 2 and Table 3) is the competence of counterparts and the success of businesses. Based on the data analysis, this relationship has a significant influence, so that the government must be able to increase the competence of SME counterparts such as the abilities in marketing, finance, production, as well as being able to motivate the owners of SMEs in Palu City. The assistance that is always provided to SMEs aims to be able to learn about effective resource management, so that these resources can increase the success of businesses (Adrian, et al., 2018; Purwatiningsih, et al., 2004; Trihudiyatmanto and Purwanto, 2018). It is known that knowledge is a fundamental thing where employees can contribute to knowledge, innovation, and ultimately can increase organizational competitive advantages (Suparwono, 2015; Jackson, et al., 2006; Liu, et al., 2004; Chang and Chuang, 2011; Sung \& Choi, 2012). The ability that is meant in this case is to include knowledge utilization as a knowledge management component within the individual of industrial owners, and they can manage their knowledge to increase the industrial income (Chen and Fong, 2015; Ganzaroli, et al., 2016; Teerajetgul and Chareonngam, 2008; Gharakhani and Mousakhani, 2012; Kuzu and Özilhan, 2014; and Alaarj et al., 2016).

The fourth hypothesis (Table 2 and Table 3) is the characteristics of ethnic entrepreneurs and the success of businesses. Based on the data analysis, there is a significant influence on these two variables. Thus, the government must be able to see and pay attention to the characteristics of group ethnic entrepreneurs in Palu City such as individuals, entrepreneurial abilities, and organizational management, since these characteristics have successful impacts on SMEs in Palu City, and the government can make decisions as a basis in industrial development in Palu City. Owning the 
level of self-awareness, a high sense of optimism, a rather good sense of empathy, and quite good social skills, are the basics that have a remarkably high impact on the success of the businesses being run (Wijayanto, 2013; Maisaroh, 2019; Hunger \& Wheelen, 2003; Steinhoff \& Burgess, 1993; Abdullah and Hadi, 2018; Pradana, 2019; and Hakim and Prajanti, 2019).

The fifth hypothesis (Table 2 and Table 3) is the marketing innovation and the success of businesses. Based on the data analysis, there is a significant influence on the two relationships. Therefore, the SMEs in Palu City must be able to make innovate their products since they can have an impact on the success of the industries. This success has been accompanied by cooperation with the government, so that the goals and targets can be achieved quickly and precisely. A lot of research has expanded their scope to include various types of innovations such as process, organization, and marketing innovations, and they have as well been examined to be effective in increasing the success of businesses. For instance, Camisón and Villar, (2014); Piening and Salge, (2015); Gupta, et al., (2016); Dehning, et al., (2007); Aarikka \& Sandberg, (2012); Chiesa \& Frattini, (2011); Sood \& Tellis, (2009); Schmidt \& Rammer, (2007); Butler, (1988); Lengick-Hall, (1992); Porter \& Stern, (2000); Han, et al., (1998); Pappas, (2015); Woodside, (2014); Knight \& Cavusgil, (2004) and Sood \& Tellis, (2009). Marketing innovation can be described as a company's ability to increase market, effectively use communication channels and deliver products and services to capture potential or existing customers (Gupta, et al., 2016; Aarikka, et al., 2012; Chiesa \& Frattini, 2011; Sood \& Tellis, 2009; Rodríguez and Crescenzi, 2008; Grewal, et al., 2004; Grimes, 1995; Hunt \& Morgan, 1996, and Slater and Narver, 1995). The resource-based organization and strategy notice that marketing innovation as a resource key that can be used by small and medium-sized producers to manage their environment, perform and even survive in difficult economic circumstances (Grewal \& Tansuhaj, 2001; Knight \& Cavusgil, 2004; Lin, et al., 2010); Ungerman, et al., 2018).

The sixth hypothesis (Table 2 and Table 3 ) is the indirect relationship between the characteristics of group ethnic entrepreneurs, the marketing innovation, and the success of businesses. Based on the data analysis, there is an indirect influence on the characteristics of group ethnic entrepreneurs through the marketing innovation towards the success of businesses, so that changes in entrepreneurial spirit influence the success of businesses when the innovation process does not change, whereas the greater the entrepreneurial attitude, the higher the success of businesses as well. Therefore, entrepreneurial abilities or competencies regarding creativity and innovation toward companies have a particularly important role for the success of their businesses (Suryana, 2003). This research is in line with Handayani and Tanjung's (2017) research which states that changes in entrepreneurial spirit influence the success of businesses when the innovation process does not change.

Based on the seventh hypothesis (Table 2 and Table 3), the competence of counterparts has a significant relationship to the success of businesses through the Marketing Innovation. The results of the counterparts who have management and technical expertise show that they can increase the success of industries through innovations in marketing. Thus, this research is in line with Adrian, et al. (2018), in their research results which show that business assistance influences the performance of MSMEs. It can be interpreted that business assistance is especially important if the SMEs in the innovation subdistricts are willing to be successful and competitive.

\section{Conclusion}

This research specifically studies the characteristics of group ethnic entrepreneurs, marketing innovation, competence of counterparts, and success of businesses. From these variables, seven hypotheses are produced in which all of these have significant influences. From the results, the regional government of Palu City and the SMEs in Palu City are expected to be able to cooperate in order to identify the characteristics of ethnic entrepreneurs from the tribes such as Kaili, Bugis, Javanese, and other ethnicities that must be considered by the government. Likewise, the marketing innovation must be considered in order to continue to be able to create innovations in marketing, especially in current technology developments. Also, training and workshops should always be implemented for the competency of counterparts owned by each SME, so that the knowledge possessed by the counterparts can be transferred to the owners of the industries. Consequently, all these variables can have a major impact on the success of SME businesses in Palu City.

\section{Acknowledgments}

On this occasion, the author would like to thank the Faculty of Economics, Tadulako University for providing financial assistance so that this research can be completed until the final stage.

\section{References}

Aarikka-Stenroos, L., \& Sandberg, B. (2012). From new-product development to commercialization through networks. Journal of Business Research, 65(2), 198-206. https://doi.org/10.1016/j.jbusres.2011.05.023 
Abdullah, N., Hadi, N. U., \& Dan Dana, P. U. (2018). The nexus between entrepreneur skills and successful business: A decompositional analysis. International Journal of Entrepreneurship and Small Business, 34(2), 249. https://doi.org/10.1504/IJESB.2018.092029

Abood, N., Aboyasin, N. A., \& Ajloni, M. I. (2014). Impact of the entrepreneurial attributes on business performance in a sample of Jordanian institutions. International Journal of Professional Management, 9(1).

Aditya, I. S., Brilianta, A., Pertiwi, W. D., \& Hartono, H. (2019). UMKM creativity development assistance through honey oatmeal product innovation at umkm body scrub. Patria's Journal, 1(1), 19-25. https://doi.org/10.24167/patria.v1i1.1909

Aji, S. P., Mulyadi, H., \& Widjajanta, B. (2018). Entrepreneurial Skills for Business Success. Journal of Business Management Education, 3(3), 111-122. https://doi.org/10.17509/jbme.v3i3.14315

Alaarj, S., Zainal, A. M., \& Bustamam, U. (2016). Mediating role of trust on the effects of knowledge management capabilities on organizational performance. Procedia - Social and Behavioral Sciences, 235(2016), 729-738. http://doi.org/10.1016/j.sbspro.2016.11.074

Anderson, J. C., \& Gerbing, D. W. (1988). Structural equation modeling in practice: a review and recommended two-step approach. Psychological Bulletin, 103(3), 411-423. https://doi.org/10.1037/0033-2909.103.3.411

Anderson, R. B., \& Dana, L. P. (2007). A multidisciplinary theory of entrepreneurship as a function of cultural perceptions of opportunity, the handbook of indigenous entrepreneurship. Edward Elgar Publishing, London.

Andreeva, T. (2011). Knowledge processes, knowledge-intensity and innovation: a moderated mediation analysis. Journal of Knowledge Management, 15(6), 1016-1034. https://doi.org/10.1108/13673271111179343

Arenius, P., \& Minniti, M. (2005). Perceptual variables and nascent entrepreneurship. Small Business Economics, 24, 233-247. https://doi.org/10.1007/s11187-005-1984-X

Bacharach, S. B. (1989). Organization theories: some criteria for evaluation. The Academy of Management Review, 14(4), 416-515. https://doi.org/10.5465/amr.1989.4308374

Bentler, P. M., \& Chou, C.-P. (1987). Practical issues in structural modeling. Sociological Methods \& Research, 16(1), 78-117. https://doi.org/10.1177/0049124187016001004

Boag, D. A., \& Dastmalchian, A. (1988). Market vulnerability and the design and management of the marketing functions in small firms. Journal of Small Business Management, 26(4), 37-45.

Butler, J. E. (1988). Theories of technological innovation as useful tools for corporate strategy. Strategic Management Journal, 5(1), 15-29. https://doi.org/10.1002/smj.4250090103

Camisón, C., \& Villar-López, A. (2014). Organizational innovation as an enabler of technological innovation capabilities and firm performance. Journal of Business Research, 67(1), 2891-2902. https://doi.org/10.1016/j.jbusres.2012.06.004

Carneiro, A. (2000). How does knowledge management influence innovation and competitiveness?. Journal of Knowledge Management, 4(2), 87-98. https://doi.org/10.1108/13673270010372242

Chang, T.-C., \& Chuang, S.-H. (2011). Performance implications of knowledge management processes: Examining the roles of infrastructure capability and business strategy. Expert Systems with Applications, 38(5), 6170-6178. http://doi.org/10.1016/j.eswa.2010.11.053

Chen, L., \& Fong, P. S. W. (2015). Evaluation of knowledge management performance: An organic approach. Information \& Management, 52(4), 431-453. https://doi.org/10.1016/j.im.2015.01.005

Chiesa, V., \& Frattini, F. (2011). Commercializing technological innovation: Learning from failures in high-tech markets. Journal of Product Innovation Management, $28(4)$, $437-454$. https://doi.org/10.1111/j.1540-5885.2011.00818.x

Chin, W. W. (1995). Partial least squares is to LISREL as principal components analysis is to common factor analysis. Technology Studies, 2, 315-319.

Cliff, J. E., Jennings, P. D., \& Greenwood, R. (2006). New to the game and questioning the rules: The experiencesnand beliefs of founders who start imitative versus innovative firms. Journal of Business Venturing, 21(5), 633-663. https://doi.org/10.1016/j.jbusvent.2005.02.010 
Cohen, W. M., \& Levinthal, D. A. (1989). Innovation and learning: The two faces of R\&D. The Economic Journal, 569-596. https://doi.org/10.2307/2233763

Cummins, D., Gilmore, A., Carson, D., \& O’Donnell, A. (2000). What is innovative marketing in SMEs? Towards a conceptual and descriptive framework.

Dana, L.-P. (2007). Toward a multidisciplinary definition of indigenous entrepreneurship. In L.-P. Dana (Ed.), International handbook of research on indigenous entrepreneurship Edward Elgar. Publishing, Great Britain. https://doi.org/10.4337/9781781952641.00008

Dehning, B., Richardson, V. J., \& Zmud, R. W. (2007). The financial performance effectsn of IT-based supply chain management systems in manufacturing firms. Journal of Operations Management, 25(4), 806-824. https://doi.org/10.1016/j.jom.2006.09.001

Disprindag. (2019). Number of field technical assistants. Palu City Industry Office.

Erliah. (2007). The effect of competition, promotion, and product uniqueness on business success (Study on Batik Crafters in Trusmi Kulon Village, Plered District, Cirebon Regency). UPI.

Flynn, L. R., \& Pearcy, D. (2001). Four subtle sins in scale development: some suggestions for strengthening the current paradigm. International Journal of Market Research, 43(4), 409-423. https://doi.org/10.1177/147078530104300404

Fuentelsaz, L., Maicas, L. P., \& Montero, J. (2018). Entrepreneurs and innovation: The contingent role of institutional factors. International Small Business Journal: Researching Entrepreneurship, 1-26. https://doi.org/10.1177/0266242618766235

Gandolfo, A., \& Padelletti, F. (1999). From direct to hybrid marketing: A new IBM go-to- market model. European Journal of Innovation Management, 2(3), 109-117. https://doi.org/10.1108/14601069910289040

Ganzaroli, A., De Noni, I., Orsi, L., \& Belussi, F. (2016). The combined effect of technological relatedness and knowledge utilization on explorative and exploitative invention performance post-M\&A. European Journal of Innovation Management, 19(2), 167-188. https://doi.org/10.1108/EJIM-08-2014-0092

Gharakhani, D., \& Mousakhani, M. (2012). Knowledge management capabilities and SMEs' organizational performance. Journal of Chinese Entrepreneurship, 4(1), 35-49. http://doi.org/10.1108/17561391211200920

Gibson, C. B., \& Birkinshaw, J. (2004). The antecedents, consequences, and mediating role of organizational ambidexterity. Academy of Management Journal, 47(2), 209-226. https://doi.org/10.2307/20159573

Government Regulations. (2018). About industrial empowerment. Republic of Indonesia State Gazette of 2018 , No. 5492. State Secretariat. Jakarta.

Grewal, D., Iyer, G. R., \& Levy, M. (2004). Internet retailing: Enablers, limiters and market consequences. Journal of Business Research, 57(7), 703-713. https://doi.org/10.1016/S0148-2963(02)00348-X

Grimes, W. S. (1995). Brand marketing, intrabrand competition, and the multibrand retailer: The antitrust law of vertical restraints. Antitrust Law Journal, 83-136.

Gunawan, S. G., Sundari, D., \& Rahayu, S. P. (2019). The effect of upsus siwab assistance on increasing animal production in East Kalimantan. Journal of Tropical Environmental Animal Husbandry, 2(2), 22-29.

Gupta, S., \& Malhotra, N. (2013). Marketing innovation: A resource-based view of interna- tional and local firms. Marketing Intelligence \& Planning, 31(2), 111-126. https://doi.org/10.1108/02634501311312026

Gupta, S., Malhotra, N. K., Czinkota, M., \& Foroudi, P. (2016). Marketing innovation: A consequence of competitiveness. Journal of Business Research, 69(12), 5671-5681. https://doi.org/10.1016/j.jbusres.2016.02.042

Hair, J. F. Jr., Black, W. C., Babin, B. J., Anderson, R. E., \& Tatham, R. L. (2006). Multivariate data analysis (6th ed.). Pearson Prentice Hall, Upper Saddle River, NJ.

Hakim, L., \& Prajanti Sucihatiningsih, D. W. (2019). The influence of entrepreneurial characteristics, managerial ability, and workforce on the success of SMEs. Economic Education Analysis Journal, 8(2), 698-712.

Han, J. K., Kim, N., \& Srivastava, R. (1998). Market orientation and organizational.

Hastuti, P. C., Thoyib, A., Troena, E. A., \& Setiawan, M. (2015, September). The minang entrepreneur characteristic. Procedia - Social and Behavioral Sciences, 211, 819-826. https://doi.org/10.1016/j.sbspro.2015.11.108 
Hendrati, A. M., \& Mulyaningsih, D. (2017). The effect of business assistance on the performance of MSMEs. E-Proceeding of Management, 4(1), 915.

Hunger, J. D., \& Thomas, L. W. (2003). Strategic management. Yogyakarta: Publisher Andi.

Hunt, S. D., \& Morgan, R. M. (1995). The comparative advantage theory of competition. The Journal of Marketing, 1-15. https://doi.org/10.1177/002224299505900201

Hunt, S. D., \& Morgan, R. M. (1996). The resource-advantage theory of competition: Dynamics, path dependencies, and evolutionary dimensions. The Journal of Marketing, 107-114. https://doi.org/10.1177/002224299606000410

Jackson, S. E., Chuang, C.-H., Harden, E. E., \& Jiang, Y. (2006). Toward developing human resource management systems for knowledge-intensive teamwork. In Research in personnel and human resources management (Vol. 25, pp. 27-70). https://doi.org/10.1016/S0742-7301(06)25002-3

Johne, A., \& Davies, R. (2000). Innovation in medium-sized insurance companies: how marketing adds value. The International Journal of Bank Marketing, 18(1), 6-14. https://doi.org/10.1108/02652320010315316

Knight, G. A., \& Cavusgil, S. T. (2004). Innovation, organizational capabilities, and the born-global firm. Journal of International Business Studies, 35(2), 124-141. https://doi.org/10.1057/palgrave.jibs.8400071

Knight, G., Omura, G. S., Hills, G. E., \& Muzyka, D. F. (1995). Research in marketing and entrepreneurship: an empirical analysis and comparison with historic trends. Conference Proceedings: Research at the Marketing/Entrepreneurship Interface (pp. 1-22). University of Illinois at Chicago, Chicago, IL.

Kuzu, Ö. H., \& Özilhan, D. (2014). The effect of employee relationships and knowledge sharing on employees' performance: an empirical research on service industry. Procedia - Social and Behavioral Sciences, 109(July 2016), 1370-1374. https://doi.org/10.1016/j.sbspro.2013.12.639

Lee, L. T., \& Sukoco, B. M. (2007). The effects of entrepreneurial orientation and knowledge management capability on organizational effectiveness in Taiwan: the moderating role of social capital. International Journal of Management, 24(3), 549-572.

Lengick-Hall, C. A. (1992). Innovation and competitive advantage: What we know and what we need to learn. Journal of Management, 18(2), 399-429. https://doi.org/10.1177/014920639201800209

Lichtenthaler, U., \& Lichtenthaler, E. (2009). A capability-based framework for open innovation: complementing absorptive capacity. Journal of Management Studies, $46(8), \quad 1315-1338$. https://doi.org/10.1111/j.1467-6486.2009.00854.X

Lin, R. J., Chen, R. H., \& Chiu, K. K. S. (2010). Customer relationship management and in-novation capability: An empirical study. Industrial Management \& Data Systems, 110(1), 111-133. https://doi.org/10.1108/02635571011008434

Liu, P. L., Chen, W. C., \& Tsai, C. H. (2004). An empirical study on the correlation between knowledge management capability and competitiveness in Taiwan's industries. Technovation, 24(12), 971-977. https://doi.org/10.1016/S01664972(03)00061-0

Maisaroh. (2019). Study of entrepreneurship characteristics of the success of SMEs (Case Study of the Convection Industry Center of Mlangi and Sawahan Nogotirto Gamping Sleman Yogyakarta). Journal of Economics, Business and Accounting (JEBA), 21(02). https://doi.org/10.32424/jeba.v21i2.1318

Marcati, A., Guido, G., \& Peluso, A. M. (2008). The role of SME entrepreneurs' innovativeness and personality in the adoption of innovations. Research Policy, 37, 1579-1590. https://doi.org/10.1016/j.respol.2008.06.004

Martinez-Conesa, I., Soto-Acosta, P., \& Carayannis, E. G. (2017). On the path towards open innovation: assessing the role of knowledge management capability and environmental dynamism in SMEs. Journal of Knowledge Management, 21(3), 553-570. https://doi.org/10.1108/JKM-09-2016-0403

McGrath, R. G., MacMillan, I. C., \& Scheinberg, S. (1992). Elitists, risk-takers, and rugged individualists? An exploratory analysis of cultural differences between entrepreneurs and nonentrepreneurs. Journal of Business Venturing, 7(1), 115-135. https://doi.org/10.1016/0883-9026(92)90008-F

Mulyana, \& Assegaf. (2015). Pengaruh knowledge Donating dan Knoledge Collecting terhadap Innovation capability kasus pengembangan UKM Batik di Provinsi Jawa Tengah Indonesia. Manajemen Tekhnologi, 14(3), $246-264$. Retrieved from http://www.ghbook.ir/index.php 
Munir, M. (2013). Living in rantau peacefully: the values of the Minangkabau people in adapting to a new cultural environment. Prosiding the 5th International, 13-14.

Nasution, A. H. (2007). Entrepreneurship membangun spirit teknopreneurship. Yogyakarta: Andi Offset.

Naudé, W. A., \& Havenga, J. J. D. (2007). An overview of African entrepreneurship and small business research. In L.-P. Dana (Ed.), International handbook of research on indigenous entrepreneurship. Edward Elgar Publishing, Cheltenham. https://doi.org/10.4337/9781781952641.00013

O'Donnell, A., \& Cummins, D. (1999). The use of qualitative methods to research networking in SMEs. Qualitative Market Research: An International Journal, 2(2), 82-91. https://doi.org/10.1108/13522759910269991

O'Dwyer, M., Gilmore, A., \& Carson, D. (2009). Innovative marketing in SMEs: a theoretical framework. European Business Review, 21(6), 504-515. https://doi.org/10.1108/09555340910998805

Palimbong, S., Renyoet, B. S., Hulu, M., Nugraha, G. A., \& Anggraeni, M. K. (2019). Training and Assistance for Cassava Bulbs Processed Innovation (Manihot sp.) For UMKM Players in the Street Vendor Business Sector in Salatiga. Journal of Community Service, 2(2), 67-72. https://doi.org/10.31970/abditani.v2i0.31

Piening, E. P., \& Salge, T. O. (2015). Understanding the antecedents, contingencies, and performance implications of process innovation: A dynamic capabilities perspective. Journal of Product Innovation Management, 32(1), 80-97. https://doi.org/10.1111/jpim.12225

Porter, M. E., \& Stern, S. (2001). Innovation: Location matters. Sloan Management Review, 42(4), 28-36.

Pradana, A. E. (2019). The influence of entrepreneurial characteristics on business success of catfish farmers in madiun city. Seminar on Management, Business and Accounting Innovation 1 PGRI Madiun University.

Pratiwi, A., Riani, A. L., Harisudin, M., \& Pinta, S. R. H. (2019). Marketing performance assistance for market oriented batik entrepreneurs. Journal of Economic Paradigm, 20(2), 1-6.

Purwatiningsih, A., \& Ismani, N. I. (2004). Factors affecting community participation in village development. Public Administration Scientific Journal.

Riyanti, B. P. D. (2007). Creativity, Self-Efficacy, and Intention to be entrepreneur among student from 4 private university in Java, Indonesia. Prosiding International Conference on Lifelong Learning.

Rodríguez-Pose, A., \& Crescenzi, R. (2008). Mountains in a flat world: Why proximity still matters for the location of economic activity. Cambridge Journal of Regions, Economy and Society, 1(3), 371-388. https://doi.org/10.1093/cjres/rsn011

Roy, S., Sivakumar, K., \& Wilkinson, I. F. (2004). Innovation generation in supply chain relationships: A conceptual model and research propositions. Journal of the Academy of Marketing Science, 32(1), 61-79. https://doi.org/10.1177/0092070303255470

Schmidt, T., \& Rammer, C. (2007). Non-technological and technological innovation: Strange bedfellows?. ZEW-Centre for European Economic Research Discussion Paper, 07-052. Retrieved from http://ftp.zew.de/pub/zew-docs/dp/dp07052.pdf

Shane, S. (2001). Technological opportunities and new firm creation. Management Science, 47(2), 205-220. https://doi.org/10.1287/mnsc.47.2.205.9837

Shergill, G. S., \& Nargundkar, R. (2005). Market orientation, marketing innovation as performance drivers. Journal of Global Marketing, 19(1), 27-47. https://doi.org/10.1300/J042v19n01_03

Sianipar, R., Sinaga, A., \& Dan Djarwowati, R. D. (2019). The influence of village facilitator characteristics on dissemination of chicken cubes innovation in malambong district, garut regency. Proceedings of the Technical Meeting for Non-Research Functional Positions, Malang.

Singh, S., Pathak, R. D., Shee, H., Kazmi, A., \& Parker, D. (2013). Interplay between entrepreneurial characteristics, organisational structure, corporate culture and SME performance: Empirical results from Fiji Islands. International Journal of Entrepreneurship and Small Business, 18(2), 229-246. https://doi.org/10.1504/IJESB.2013.052076

Slater, S. F., \& Narver, J. C. (1995). Market orientation and the learning organization. Journal of Marketing, 63-74. https://doi.org/10.1177/002224299505900306 
Sood, A., \& Tellis, G. J. (2009). Do innovations really pay off? Total stock market returns to innovation. Marketing Science, 28(3), 442-456. https://doi.org/10.1287/mksc.1080.0407

Steinhoff, D., \& Burgess, J. F. (1993). Small business management fundamentals. New York-USA. McGraw-Hill, Inc.

Stokes, D. (1995). Small business management (2nd ed.). DP Publishing, London.

Sung, S. Y., \& Choi, J. N. (2012). Effects of team knowledge management on the creativity and financial performance of organizational teams. Organizational Behavior and Human Decision Processes, 118(1), 4-13. https://doi.org/10.1016/j.obhdp.2012.01.001

Suparwono. (2015). The influence of entrepreneurship competence and orientation on business performance (Case Study at the Pande Besi UMKM Center in Krasak Village, Mojotengah District). FE UNSIQ Thesis.

Suryana. (2013). Entrepreneurship. Jakarta: Four Salemba.

Taghizadeh, S. K., Rahman, S. A., \& Marimuthu, M. (2020). Idea generation leveraged from value cocreation process enhances new service development performance. Journal of Strategic Marketing, 27(6), 483-504. https://doi.org/10.1080/0965254X.2018.1430052

Teerajetgul, W., \& Chareonngam, C. (2008). Tacit knowledge utilization in Thai construction projects. Journal of Knowledge Management, 12, 164-174. https://doi.org/10.1108/13673270810852467

Valliere, D. (2013). Towards a schematic theory of entrepreneurial alertness. Journal of Business Venturing, 28, 430-442. https://doi.org/10.1016/j.jbusvent.2011.08.004

Venkataraman, S. (1997). The distinctive domain of entrepreneurship research: An editor's perspective. In J. Katz, \& R. Crokhaus (Eds.), Advances in Entrepreneurship, Firm Emergence, and Growth (pp. 119-138). Greenwich, CT: JAI Press.

Wang, C. L., \& Altinay, L. (2012). Social embeddedness, entrepreneurial orientation and firm growth in ethnic minority small businesses in the UK. International Small Business Journal, 30(1), 3-23. https://doi.org/10.1177/0266242610366060

Wijayanto, A. (2013). The influence of entrepreneur characteristics on the success level of study efforts at fish smoking small business centers in krobokan Semarang. Journal of Social Sciences, 12(1), 16-28.

\section{Copyrights}

Copyright for this article is retained by the author(s), with first publication rights granted to the journal.

This is an open-access article distributed under the terms and conditions of the Creative Commons Attribution license (http://creativecommons.org/licenses/by/4.0/). 